\title{
Introduction to the 2020 Special Section Theme: the Future of Health Sciences Education
}

\author{
Peter G. M. de Jong ${ }^{1}$ \\ Accepted: 18 October 2020 / Published online: 29 October 2020 \\ (C) International Association of Medical Science Educators 2020
}

In 2015, Medical Science Educator introduced “journal sections" on a specific topic. These thematic sections are the successor of the special issues that were published annually in the years before that. The content for the thematic sections is solicited by a special call for manuscripts. This year we are publishing a special journal section dedicated to the topic of "The Future of Health Sciences Education."

In this 2020 issue, the journal would like to explore best practices from institutions around the world where innovations in teaching and learning take place, where new teaching strategies are being implemented, and where educational solutions are being developed to better prepare for global changes in health care in the future. Changes, improvements, and innovations in the field of health education are ongoing and already date back more than a century. Since then the landscape of education has changed enormously, not least of all due to the rise of computer technologies. Technological, pedagogical, societal, financial, environmental, and many other influences continuously impact our teaching systems. And who could have predicted when the call was sent out late
2019 that the practice of education would already be drastically changed a few months later due to COVID-19? This begs the question: what future can we expect and what will be the impact on the role of the educator?

The journal received over 40 submissions for this special journal section. In this issue of Medical Science Educator, I present to you the first 16 published manuscripts. Some manuscripts are still in revision or production and will be published in one of the upcoming regular journal issues. I hope that the articles in this section are of interest to you and will be an inspiration for medical education leaders to help shape the future.

Peter GM de Jong, PhD

Editor-in-Chief

Publisher's Note Springer Nature remains neutral with regard to jurisdictional claims in published maps and institutional affiliations.
Peter G. M. de Jong

P.G.M.de_Jong@lumc.nl

1 Leiden University Medical Center, Leiden, The Netherlands 